\title{
Auranofin and its Analogues Show Potent Antimicrobial Activity Covering Multiresistant Pathogens: Structure-Activity Relationships
}

\author{
Tiziano Marzo, ${ }^{[a, b]} \neq$ Damiano Cirri, ${ }^{[b]} \neq$ Simona Pollini, ${ }^{[c, d]}$ Marco Prato, ${ }^{[c]}$ Stefania Fallani, ${ }^{[e]}$ Maria Iris \\ Cassetta, ${ }^{[e]}$ Andrea Novelli, ${ }^{[e]}$ Gian Maria Rossolini, ${ }^{*[c, d]}$, Luigi Messori, ${ }^{* b]}$ \\ Da] T. Marzo
Department of Chemistry and Industrial Chemistry (DCCl), University of Pisa, Via Moruzzi, 13, 56124 Pisa, Italy. \\ [b] D. Cirri, Prof. L. Messori, Dr. T. Marzo \\ Laboratory of Metals in Medicine (MetMed), Department of Chemistry "U. Schiff”, University of Florence, Via della Lastruccia 3, 50019, Sesto Fiorentino, \\ Italy. E-mail: luigi.messori@unifi.it \\ [c] Dr. S. Pollini, M. Prato, Prof. G.M. Rossolini \\ Department of Experimental and Clinical Medicine (DMSC), University of Florence, Largo Brambilla 3, 50134, Firenze, Italy. E-mail: \\ gianmaria.rossolini@unifi.it \\ [d] Dr. S. Pollini, Prof. G.M. Rossolini, \\ Microbiology and Virology Unit, Azienda Ospedaliero-Universitaria Careggi (AOUC), Largo Brambilla 3, 50134, Firenze, Italy. \\ [e] Dr. S. Fallani, Dr. M.I. Cassetta, Prof. A. Novelli \\ Department of Healt Sciences (DSS), University of Florence, Viale Pieraccini 6, 50139, Florence, Italy.
}

‡These authors equally contributed.

Supporting information for this article is given via a link at the end of the document.

\begin{abstract}
Due to the so called "antibiotic resistance crisis" new antibacterial agents are urgently sought to treat multi-resistant pathogens. A group of gold- or silver-based complexes, of general formula $\mathrm{M}\left(\mathrm{PEt}_{3}\right) \mathrm{X}$ (with $\mathrm{M}=\mathrm{Au}$ or $\mathrm{Ag}$, and $\mathrm{X}=\mathrm{Cl}, \mathrm{Br}$ or I), alongside with three complexes bearing a positive or negative charge, i.e. $\left[\mathrm{Au}\left(\mathrm{PEt}_{3}\right)_{2}\right] \mathrm{Cl}, \mathrm{K}\left[\mathrm{Au}(\mathrm{CN})_{2}\right]$ and $\left[\mathrm{Ag}\left(\mathrm{PEt}_{3}\right)_{2}\right] \mathrm{NO}_{3}$, have been prepared and comparatively tested with Auranofin (AF) toward a representative panel of pathogens including Gram-positive, Gram-negative and Candida strains. Interestingly, all tested gold and silver complexes are active on Gram-positive strains, with the gold complexes presenting a greater efficacy. The effects of the gold compounds are potentiated to a larger extent than silver compounds when tested in combination with a permeabilizing agent. A few relevant structure-activity relationships emerge from comparative analysis of the obtained antibacterial profiles shedding new light on the underlying molecular mechanisms.
\end{abstract}

\section{Introduction}

Several metals and metal-based compounds have been used for centuries as anti-infective agents on a simple empirical basis with some appreciable results. For instance, the complex dicyanoaurate(I) was proposed and used by Koch as an antitubercular agent in the pioneering times of modern pharmacology while several bismuth, antimony and mercury compounds have been extensively employed to combat various bacterial and parasitic diseases. ${ }^{1-4}$ Yet, more recently, due to the advent of the golden era of antibiotics and to grounded concerns on their systemic toxicity, metal-based agents were gradually abandoned. Only a few exceptions survived in the clinics for specific therapeutic indications, such as bismuth salts for the eradication of helicobacter pylori infection, and antimony compounds as anti-leishmanial agents. ${ }^{3,5}$
However, during the last two decades, the so called "antibiotic resistance crisis", arising from the emergence of bacterial strains with multidrug-resistant (MDR) and extensively drug-resistant (XDR) phenotypes and from the simultaneous decline in the discovery rate of new and effective antibiotic molecules, has posed the dramatic problem of finding out new substances capable of fighting life-threatening infections caused by these pathogens. ${ }^{6,7}$ Metal-based compounds are thus being reconsidered as a rich source of antimicrobial agents often endowed with innovative modes of action. In this context auranofin (AF), an antiarthritic agent still sporadically used to treat some severe forms of rheumatoid arthritis, has been revisited, in the frame of drug repurposing strategies, with rather promising results. Indeed, remarkable antimicrobial and antiparasitic properties were disclosed for this oral gold(I) drug, that has become the reference compound even for the development of novel gold-based antibacterial agents or specific inhibitors of important enzymes. ${ }^{7,8}$ Some recent studies explored in detail the mechanistic aspects of its antimicrobial action; it was shown that AF probably acts through a multifactorial and multitarget mechanism and that the low susceptibility of Gram-negative bacteria to this drug is probably the consequence of a reduced intracellular gold accumulation. ${ }^{9-12}$ Yet, the precise mechanisms of the antimicrobial action of AF and the respective biomolecular targets are not known.

The promising antibacterial properties disclosed for AF prompted us to test not only AF but also a series of related metal complexes, prepared in our laboratory, against a panel of isolates, including major Gram-positive, Gram-negative and fungal pathogens and showing relevant resistance phenotypes. Some classical gold complexes were prepared and evaluated as well. We thought that the comparative analysis of the antimicrobial behavior of the various structurally-related gold(I) and silver(I) complexes might provide valuable mechanistic insight on $\mathrm{AF}$ and its derivatives and 
might lead to drug improvement through chemical modification as well as to a better understanding of the observed pharmacological effects.

\section{Results and Discussion}

The panel of studied gold and silver compounds is schematically represented in figure 1. For gold-based complexes the panel includes, beyond $\mathrm{AF}$, three gold complexes of general formula $\mathrm{Au}\left(\mathrm{PEt}_{3}\right) \mathrm{X}$ where $\mathrm{X}$ is a halide ligand; these latter compounds are known AF analogues where the thiosugar ligand is replaced by chloride, bromide or iodide. ${ }^{13}$ The cationic diphosphino gold(I) and the anionic dicyanoaurate $(\mathrm{I})$ complexes, prepared according to reported procedures, were also included in the panel (see the experimental section and supporting material for details on their synthesis, CHN analysis, NMR and UV-Vis characterization). ${ }^{14}$

\section{$\mathrm{Et}_{3} \mathrm{P}-\mathrm{M}-\mathbf{X}$}

\begin{aligned} \hline Metal centers and substituents \\ $\mathbf{X}=\mathrm{Cl}, \mathrm{Br}, \mathrm{I}, \mathrm{AcOAC} \\ \mathbf{M}=\mathrm{Au}, \mathrm{Ag}\end{aligned}$

Some preliminary information was available on the nature of these molecules and their solution chemistry. ${ }^{13 c}$

Here, we have expanded the investigation of the solution behavior of the whole panel, under different solution conditions. From ${ }^{31} \mathrm{P}$ NMR experiments we observe that, when working in DMSO, the release of the halide ligand in the $\mathrm{Au}\left(\mathrm{PEt}_{3}\right) \mathrm{X}$ series does not occur. $A$ rather similar situation was found in PBS despite $\mathrm{Au}\left(\mathrm{PEt}_{3}\right) \mathrm{Br}$ and $\mathrm{Au}\left(\mathrm{PEt}_{3}\right) \mathrm{I}$ undergo a scrambling reaction leading to a peak falling at $47 \mathrm{ppm}$ assignable to the cationic diphosphino gold(I) complex (although in a very limited amount) especially upon long incubation times. ${ }^{13 c}$ Even when incubated in the biological media used for the biological testing $\mathrm{Au}\left(\mathrm{PEt}_{3}\right) \mathrm{Cl}, \mathrm{Au}\left(\mathrm{PEt}_{3}\right) \mathrm{Br}$ and $\mathrm{Au}\left(\mathrm{PEt}_{3}\right)$ I remain stable and no halide release occurs. It is worthy to note that in the same conditions also AF does not undergo changes. A high stability in these conditions was found also for the cationic and anionic complexes (see the supporting material for details and spectra).

Next, the gold compounds were evaluated toward a panel of Gram-positive isolates of clinical origin, including MDR and XDR strains, and also a clinical isolate of Candida albicans (table 1). MIC values for the tested compounds, determined according to reference methods, are reported in table 1.

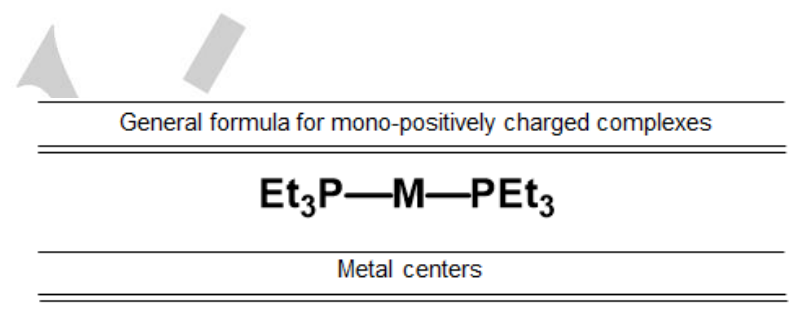

$\mathrm{M}=\mathrm{Au}, \mathrm{Ag}$

$\overline{\text { Mono-negatively charged complex }}$

Figure 1. The panel of the investigated gold and silver complexes. For clarity, the structure of neutral silver complex, has been here reported in a simplified manner. It should be noted that these species are tetrameric with a structure of the type $\left[\mathrm{Ag}\left(\mathrm{PEt}_{3}\right) \mathrm{X}\right]_{4}$ (see below in this section). 
Table 1. MIC $(\mu \mathrm{g} / \mathrm{mL}$ and $\mu \mathrm{M})$ values obtained for gold compounds on Gram-positive strains and Candida albicans (strain 14).

\begin{tabular}{|c|c|c|c|c|c|c|c|c|c|c|c|c|c|}
\hline \multirow{2}{*}{ Strain $^{\mathrm{a}}$} & \multirow{2}{*}{ R profile ${ }^{b}$} & \multicolumn{2}{|c|}{$\mathbf{A F}$} & \multicolumn{2}{|c|}{$\mathbf{A u}\left(\mathbf{P E t}_{3}\right) \mathbf{C l}$} & \multicolumn{2}{|c|}{$\mathbf{A u}\left(\mathbf{P E t}_{3}\right) \mathbf{B r}$} & \multicolumn{2}{|c|}{$\mathbf{A u}\left(\mathbf{P E t}_{3}\right) \mathbf{I}$} & \multicolumn{2}{|c|}{$\left[\mathrm{Au}\left(\mathrm{PEt}_{3}\right)_{2}\right] \mathrm{Cl}$} & \multicolumn{2}{|c|}{$\mathrm{K}\left[\mathrm{Au}(\mathrm{CN})_{2}\right]$} \\
\hline & & $\mu \mathrm{g} / \mathrm{mL}$ & $\mu \mathrm{M}$ & $\mu \mathrm{g} / \mathrm{mL}$ & $\mu \mathrm{M}$ & $\mu \mathrm{g} / \mathrm{mL}$ & $\mu \mathrm{M}$ & $\mu \mathrm{g} / \mathrm{mL}$ & $\mu \mathrm{M}$ & $\mu \mathrm{g} / \mathrm{mL}$ & $\mu \mathrm{M}$ & $\mu \mathrm{g} / \mathrm{mL}$ & $\mu \mathrm{M}$ \\
\hline 1 & Reference strain, wild type & 0,062 & 0,09 & $\leq 0,062$ & $\leq 0,18$ & $\leq 0,062$ & $\leq 0,16$ & $\leq 0,062$ & $\leq 0,14$ & $\leq 0,062$ & $\leq 0,13$ & 8 & 27,77 \\
\hline 2 & $\mathrm{OXA}^{\mathrm{r}} \mathrm{CL}^{\mathrm{r}} \mathrm{ERY}^{\mathrm{r}} \mathrm{LIN}^{\mathrm{r}} \mathrm{FQ}^{\mathrm{r}} \mathrm{AG}^{\mathrm{r}}$ & 0,062 & 0,09 & $\leq 0,062$ & $\leq 0,18$ & $\leq 0,062$ & $\leq 0,16$ & $\leq 0,062$ & $\leq 0,14$ & $\leq 0,062$ & $\leq 0,13$ & 0,5 & 1,73 \\
\hline 3 & Reference strain, wild type & $\leq 0,062$ & $\leq 0,09$ & $\leq 0,062$ & $\leq 0,18$ & $\leq 0,062$ & $\leq 0,16$ & 0,062 & 0,14 & $\leq 0,062$ & $\leq 0,13$ & 0,25 & 0,87 \\
\hline 4 & LIN $^{\mathrm{r}}$ & 0,062 & 0,09 & $\leq 0,062$ & $\leq 0,18$ & $\leq 0,062$ & $\leq 0,16$ & $\leq 0,062$ & $\leq 0,14$ & $\leq 0,062$ & $\leq 0,13$ & 0,5 & 1,73 \\
\hline 5 & $\mathrm{AG}^{\mathrm{r}}$ & 0,25 & 0,37 & $\leq 0,062$ & $\leq 0,18$ & $\leq 0,062$ & $\leq 0,16$ & 0,062 & 0,14 & $\leq 0,062$ & $\leq 0,13$ & 0,5 & 1,73 \\
\hline 6 & $-^{\mathrm{c}}$ & 0,125 & 0,18 & $\leq 0,062$ & $\leq 0,18$ & $\leq 0,062$ & $\leq 0,16$ & 0,062 & 0,14 & $\leq 0,062$ & $\leq 0,13$ & 0,25 & 0,87 \\
\hline 7 & - & 0,062 & 0,09 & $\leq 0,062$ & $\leq 0,18$ & 0,062 & 0,16 & 0,062 & 0,14 & $\leq 0,062$ & $\leq 0,13$ & 2 & 6,94 \\
\hline 8 & $\mathrm{AMP}^{\mathrm{r}} \mathrm{VAN}^{\mathrm{r}} \mathrm{AG}^{\mathrm{r}}$ & 0,125 & 0,02 & $\leq 0,062$ & $\leq 0,18$ & 0,062 & 0,16 & 0,062 & 0,14 & $\leq 0,062$ & $\leq 0,13$ & 2 & 6,94 \\
\hline 9 & AMP $^{r}$ ESC $^{r}$ & 0,062 & 0,09 & $\leq 0,062$ & $\leq 0,18$ & 0,062 & 0,16 & 0,062 & 0,14 & $\leq 0,062$ & $\leq 0,13$ & 1 & 3,47 \\
\hline 10 & $\mathrm{AMP}^{\mathrm{r}}$ & 0,062 & 0,09 & $\leq 0,062$ & $\leq 0,18$ & 0,125 & 0,32 & 0,062 & 0,14 & $\leq 0,062$ & $\leq 0,13$ & 0,5 & 1,73 \\
\hline 11 & - & 0,125 & 0,18 & $\leq 0,062$ & $\leq 0,18$ & $\leq 0,062$ & $\leq 0,16$ & 0,125 & 0,28 & 0,125 & 0,27 & 0,062 & 0,21 \\
\hline 12 & $\mathrm{ESC}^{\mathrm{r}} \mathrm{CL}^{\mathrm{r}} \mathrm{AG}^{\mathrm{r}}$ & $\leq 0,062$ & $\leq 0,09$ & $\leq 0,062$ & $\leq 0,18$ & $\leq 0,062$ & $\leq 0,16$ & $\leq 0,062$ & $\leq 0,14$ & $\leq 0,062$ & $\leq 0,13$ & 2 & 6,94 \\
\hline 13 & $\mathrm{AMP}^{\mathrm{r}} \mathrm{CL}^{\mathrm{r}} \mathrm{AG}^{\mathrm{r}}$ & $\leq 0,062$ & $\leq 0,09$ & $\leq 0,062$ & $\leq 0,18$ & $\leq 0,062$ & $\leq 0,16$ & $\leq 0,062$ & $\leq 0,14$ & $\leq 0,062$ & $\leq 0,13$ & 8 & 27,77 \\
\hline 14 & - & $>8$ & $>11,80$ & 2 & 5,70 & 4 & 10,12 & 8 & 18,10 & $>8$ & $>17,07$ & $>8$ & $>27,77$ \\
\hline
\end{tabular}

a Clinical strains: 1. Staphylococcus aureus ATCC 25923; 2. Staphylococcus epidermidis FI-1; 3. Enterococcus faecalis ATCC 29212; 4. Enterococcus faecalis FI2; 5. Enterococcus faecalis $\mathrm{FI}-3 ; \mathbf{6}$. Enterococcus faecalis $\mathrm{FI}-4 ; \mathbf{7}$. Enterococcus faecium $\mathrm{FI}-5 ; \mathbf{8}$. Enterococcus faecium $\mathrm{FI}-6$; 9 . Streptococcus salivarius $\mathrm{FI}-7$; 10. Streptococcus parasanguinis FI-8; 11. Streptococcus pyogenes FI-9; 12. Corynebacterium striatum FI-10; 13. Corynebacterium striatum FI-11; 14. Candida albicans $\mathrm{Fl}-12$.

${ }^{b}$ Resistance phenotype of the clinical strains; AMPr, resistant to ampicillin; OXAr, oxacillin-resistant; ESCr, resistant to expanded-spectrum cephalosporins; CLr, resistant to clindamycin; ERYr, resistant to erythromycin; LINr, resistant to linezolid; VANr, resistant to vancomycin; FQr, resistant to fluoroquinolones (levofloxacin and/or ciprofloxacin); AGr, resistant to aminoglycosides (gentamicin and/or amikacin and/or tobramycin).

$c_{-}$: strain with no reported resistance phenotypes.

Careful analysis of the obtained results provides valuable hints on a few relevant structure-function relationships. In line with expectations, AF shows a consistent antimicrobial activity against all tested Gram-positive species, though with some appreciable differences in potency, being instead poorly active against $C$. albicans.

It is interesting to compare the behavior of the $\mathrm{Au}\left(\mathrm{PEt}_{3}\right) \mathrm{X}$ species with AF. Remarkably, the $\mathrm{Au}\left(\mathrm{PEt}_{3}\right) \mathrm{X}$ compounds show relevant antimicrobial properties against Gram-positive bacteria, with a potency that is comparable or slightly lower than AF. Also, the antibacterial profiles of the three $\mathrm{Au}\left(\mathrm{PEt}_{3}\right) \mathrm{X}$ complexes against these pathogens are very similar to one another, being almost superimposable. These observations imply that the thiosugar ligand is not essential for the antimicrobial activity of AF. Similarly, the nature of the $X$ group seems to play a minor role -if any- in determining the antimicrobial profiles of the three $\mathrm{Au}\left(\mathrm{PEt}_{3}\right) \mathrm{X}$ compounds, that are nearly identical. Altogether, these results point to the $\left[\mathrm{Au}\left(\mathrm{PEt}_{3}\right)\right]^{+}$moiety as the "true pharmacophore". The strong similarity in the antimicrobial activity of the three $\mathrm{Au}\left(\mathrm{PEt}_{3}\right) \mathrm{X}$ complexes also suggests that their uptake is similar or -at leastnot very different from one another. Similarly to $A F$, the three $\mathrm{Au}\left(\mathrm{PEt}_{3}\right) \mathrm{X}$ compounds are less active against $C$. albicans.

To expand our analysis of structure-function relationships, the two charged gold(I) compounds were then evaluated. Very interestingly, the cationic diphosphine complex conserved important antimicrobial properties similar to those of $\mathrm{Au}\left(\mathrm{PEt}_{3}\right) \mathrm{X}$ complexes. Again, this suggests that a single phosphine ligand is sufficient for the biological activity.

In contrast, the dicyano gold(I) complex resulted far less active than $\left[\mathrm{Au}\left(\mathrm{PEt}_{3}\right)_{2}\right] \mathrm{Cl}$. This observation may imply either that the negatively charged dicyano gold(I) complex is taken up less efficiently than neutral or positive gold complexes or that the cyanide ligand is so strong that the biological action of the gold (I) center -probably linked to gold(I) coordination to a specific biomolecular target- is greatly inhibited. When considering this latter aspect, worthy of attention is the comparison of the antimicrobial properties of two carbene complexes with R-C-Au$\mathrm{C}-\mathrm{R}$ and $\mathrm{R}-\mathrm{C}-\mathrm{Au}-\mathrm{Cl}$ structures ( $\mathrm{R}=1,3-$ dimethylimidazolium), that we tested previously on different bacterial strains. We observed that the former compound is far less active than the latter on a Gram-positive strain (i.e. staphylococcus aureus ATCC 2592). This lower activity is likely related to the greater stability of the complexes with R-C-Au-C-R structures. ${ }^{15,16}$ Conversely, the larger antimicrobial effects of the monocarbene gold complex, where $\mathrm{Cl}^{-}$acts as a labile ligand, seems to support -at least indirectly- that its biological activity is linked to the ease of ligand displacement and to consequent gold coordination to relevant biological targets (unpublished results, see the supporting information for MIC values and carbene structures).

As previously reported, AF is scarcely active on Gram-negative strains being this tentatively attributed to a reduced drug uptake. ${ }^{10}$ To confirm these evidences and assess whether such limited activity of gold compounds in Gram-negative bacteria is "conserved" upon replacement of thiosugar with different ligands, we investigated the antibacterial effects of the experimental drugs on five Gram-negative strains of clinical origin. Also, to go further in the understanding of the underlying mechanistic aspects, we repeated the same experiments on Gram-negative isolates in the presence of the permeabilizing agent polymyxin $B$ nonapeptide (PMBN). The MIC values are summarised in table 2. 
Table 2. MIC ( $\mu \mathrm{g} / \mathrm{mL}$ and $\mu \mathrm{M})$ values obtained for gold compounds in Gram-negative strains in absence or in presence of polymyxin B nonapeptide (PMBN) as permeabilizing agent.

\begin{tabular}{|c|c|c|c|c|c|c|c|c|c|c|c|c|c|}
\hline \multirow{2}{*}{ Strain $^{\text {a }}$} & \multirow[t]{2}{*}{ R profile ${ }^{b}$} & \multicolumn{2}{|c|}{$\mathbf{A F}$} & \multicolumn{2}{|c|}{$\begin{array}{c}\text { AF } \\
\text { PMBN }\end{array}$} & \multicolumn{2}{|c|}{$\mathbf{A u}\left(\mathbf{P E t}_{3}\right) \mathbf{C l}$} & \multicolumn{2}{|c|}{ Au(PEt ( $\left._{3}\right) \mathrm{Cl}$ PMBN } & \multicolumn{2}{|c|}{$\mathbf{A u}\left(\mathbf{P E t}_{3}\right) \mathbf{B r}$} & \multicolumn{2}{|c|}{ Au(PEt $\left.t_{3}\right)$ Br PMBN } \\
\hline & & $\mu \mathrm{g} / \mathrm{mL}$ & $\mu \mathrm{M}$ & $\mu \mathrm{g} / \mathrm{mL}$ & $\mu \mathrm{M}$ & $\mu \mathrm{g} / \mathrm{mL}$ & $\mu \mathrm{M}$ & $\mu \mathrm{g} / \mathrm{mL}$ & $\mu \mathrm{M}$ & $\mu \mathrm{g} / \mathrm{mL}$ & $\mu \mathrm{M}$ & $\mu \mathrm{g} / \mathrm{mL}$ & $\mu \mathrm{M}$ \\
\hline 15 & $\mathrm{ESC}^{\mathrm{r}} \mathrm{NEM}^{\mathrm{r}} \mathrm{FQ}^{\mathrm{r}} \mathrm{AG}^{\mathrm{r}}$ & $>32$ & $>47,09$ & 1 & 1,47 & 4 & 11,41 & 1 & 2,85 & 4 & 10,12 & 0,5 & 1,26 \\
\hline 16 & $\mathrm{ESC}^{\mathrm{r}} \mathrm{NEM}^{\mathrm{r}} \mathrm{FQ}^{\mathrm{r}} \mathrm{AG}^{\mathrm{r}} \mathrm{COL}^{\mathrm{r}}$ & $>32$ & $>47,09$ & 8 & 11,77 & 4 & 11,41 & 2 & 5,70 & 4 & 10,12 & 2 & 5,06 \\
\hline 17 & $\mathrm{ESC}^{\mathrm{r}} \mathrm{NEM}^{\mathrm{r}} \mathrm{FQ}^{\mathrm{r}} \mathrm{AG}^{\mathrm{r}}$ & $>32$ & $>47,09$ & $\leq 0,25$ & $\leq 0,37$ & $>8$ & $>22,82$ & 0,125 & 0,36 & $>8$ & $>20,25$ & 0,125 & 0,32 \\
\hline 18 & $\mathrm{NEM}^{\mathrm{r}} \mathrm{FQ}^{\mathrm{r}} \mathrm{AG}^{\mathrm{r}}$ & 32 & $>47,09$ & 2 & 2,94 & 4 & 11,41 & 0,5 & 1,43 & 4 & 10,12 & 0,5 & 1,26 \\
\hline 19 & $-\mathrm{c}$ & 16 & $>23,55$ & 1 & 1,47 & 4 & 11,41 & 0,5 & 1,43 & 4 & 10,12 & 0,5 & 1,26 \\
\hline \multirow[t]{2}{*}{ Strain $^{\text {a }}$} & \multirow[t]{2}{*}{ R profile ${ }^{\mathrm{b}}$} & \multicolumn{2}{|c|}{$\operatorname{Au}\left(\mathbf{P E t}_{3}\right) \mathbf{I}$} & \multicolumn{2}{|c|}{$\mathbf{A u}\left(\mathbf{P E t}_{3}\right) \mathbf{I}$ PMBN } & \multicolumn{2}{|c|}{$\left[\mathbf{A u}\left(\mathbf{P E t}_{3}\right)_{2}\right] \mathbf{C l}$} & \multicolumn{2}{|c|}{$\left[\mathrm{Au}\left(\mathrm{PEt}_{3}\right)_{2}\right] \mathrm{Cl}$ PMBN } & \multicolumn{2}{|c|}{$\mathrm{K}\left[\mathrm{Au}(\mathrm{CN})_{2}\right]$} & \multicolumn{2}{|c|}{$\mathrm{K}\left[\mathrm{Au}(\mathrm{CN})_{2}\right] \mathrm{PMBN}$} \\
\hline & & $\mu \mathrm{g} / \mathrm{mL}$ & $\mu \mathrm{M}$ & $\mu \mathrm{g} / \mathrm{mL}$ & $\mu \mathrm{M}$ & $\mu \mathrm{g} / \mathrm{mL}$ & $\mu \mathrm{M}$ & $\mu \mathrm{g} / \mathrm{mL}$ & $\mu \mathrm{M}$ & $\mu \mathrm{g} / \mathrm{mL}$ & $\mu \mathrm{M}$ & $\mu \mathrm{g} / \mathrm{mL}$ & $\mu \mathrm{M}$ \\
\hline 15 & $\mathrm{ESC}^{\mathrm{r}} \mathrm{NEM}^{\mathrm{r}} \mathrm{FQ}^{\mathrm{r}} \mathrm{AG}^{\mathrm{r}}$ & 4 & 9,05 & 0,5 & 1,13 & 16 & 34,13 & 0,5 & 1,07 & 16 & 55,54 & 8 & 27,77 \\
\hline 16 & $\mathrm{ESC}^{\mathrm{r}} \mathrm{NEM}^{\mathrm{r}} \mathrm{FQ}^{\mathrm{r}} \mathrm{AG}^{\mathrm{r}} \mathrm{COL}^{\mathrm{r}}$ & 4 & 9,05 & 2 & 4,52 & 16 & 34,13 & 1 & 2,13 & 16 & 55,54 & 8 & 27,77 \\
\hline 17 & $\mathrm{ESC}^{\mathrm{r}} \mathrm{NEM}^{\mathrm{r}} \mathrm{FQ}^{\mathrm{r}} \mathrm{AG}^{\mathrm{r}}$ & $>8$ & $>18,10$ & 0,25 & 0,56 & $>32$ & $>68,27$ & $\leq 0,25$ & $\leq 0,53$ & 16 & 55,54 & 1 & 3,74 \\
\hline 18 & $\mathrm{NEM}^{\mathrm{r}} \mathrm{FQ}^{\mathrm{r}} \mathrm{AG}^{\mathrm{r}}$ & 4 & 9,05 & 0,5 & 1,13 & 8 & 17,07 & 0,5 & 1,07 & 16 & 55,54 & 8 & 27,77 \\
\hline 19 & $-\mathrm{c}$ & 4 & 9,05 & 0,5 & 1,13 & 8 & 17,07 & 0,25 & 0,53 & 8 & 27,77 & 4 & 13,88 \\
\hline
\end{tabular}

a Clinical strains: 15. Escherichia coli CV287; 16. Klebsiella pneumoniae KKBO4; 17. Pseudomonas aeruginosa Vr143/97; 18. Acinetobacter baumannii FI-13; 19. Stenotrophomonas maltophilia FI-14.

${ }^{b}$ Resistance phenotype of the clinical strains; ESCr, resistant to expanded-spectrum cephalosporins; NEMr, resistance to carbapenems (imipenem and/or meropenem); FQr, resistant to fluoroquinolones (levofloxacin and/or ciprofloxacin); AGr, resistant to aminoglycosides (gentamicin and/or amikacin and/or tobramycin); COLr, resistant to colistin.c -: strain with no reported resistance phenotypes.

According with the data already reported in the literature, AF in poorly active. ${ }^{10}$ Though, in general, $\mathrm{Au}\left(\mathrm{PEt}_{3}\right) \mathrm{X}$ analogues, similarly to $\left[\mathrm{Au}\left(\mathrm{PEt}_{3}\right)_{2}\right] \mathrm{Cl}$ show a slightly greater activity than $\mathrm{AF}$ toward the six Gram-negative strains, their potency is still significantly lower than in Gram-positive isolates. Again, the dicyano gold(I) complex is the least active complex of the panel. However, when these gold compounds are administered in combination with the permeabilizing agent PMBN, a marked increase of the antibacterial effects was observed for $A F$ and the $\mathrm{Au}\left(\mathrm{PEt}_{3}\right) \mathrm{X}$ series as well as for $\left[\mathrm{Au}\left(\mathrm{PEt}_{3}\right)_{2}\right] \mathrm{Cl}$, confirming that the reported difficulties in gold uptake documented for $A F$ do persist for $\mathrm{Au}\left(\mathrm{PEt}_{3}\right) \mathrm{X}$ complexes. For $\mathrm{K}\left[\mathrm{Au}(\mathrm{CN})_{2}\right]$, even in the presence of PMBN, no significant increase of the antibacterial effects was observed. This may offer indirect confirmation that the very strong coordination of the cyanide ligand to the gold(I) center accounts for the poor antibacterial effects due to lack of ligand dissociation and of gold binding to bacterial targets. Interestingly, the MIC values determined for strain 17 (Pseudomonas aeruginosa Vr143/97) decreased markedly for all compounds when tested in the presence of PMBN, including the anionic dicyanide complex; this strong effect may probably arise from the intrinsic higher susceptibility to PMBN already observed for this strain. ${ }^{17}$ Of note, a lower decrease of MIC values in the presence of PMBN was observed for some compounds (e.g. $\mathrm{AF}$ and $\mathrm{Au}\left(\mathrm{PEt}_{3}\right) \mathrm{X}$ ) for strain 16 (Klebsiella pneumoniae KKBO4); this strain shows a resistant

phenotype to polymyxins (table 2) due to an alteration of the outer membrane lipopolysaccharide, that is also likely responsible for the lower susceptibility of this strain to the permeabilizing action of PMBN. ${ }^{18}$

The above results and their implications prompted us to prepare a second set of compounds, strictly related to the gold panel, consisting of four distinct silver(I) complexes (figure 1).
The three silver compounds, of general simplified formula $\mathrm{Ag}\left(\mathrm{PEt}_{3}\right) \mathrm{X}$, and the diphosphine cationic complex were prepared and characterized as reported in the experimental section and in the supporting material. $\mathrm{Ag}\left(\mathrm{PEt}_{3}\right) \mathrm{X}$ complexes are known since decades; studies carried out by Churchill et al. pointed out that in the solid state these complexes possess a $\left[\mathrm{Ag}\left(\mathrm{PEt}_{3}\right) \mathrm{X}\right]_{4}$ "cubanelike" skeleton of alternating silver and halogen. ${ }^{20}$ In analogy with gold compounds, the solution behavior of the silver complexes was assessed through NMR spectroscopy in dimethyl sulfoxide, PBS and in the presence of the media used for the biological experiments (details and spectra in the supporting material). A large stability for the studied complexes was detected both in organic solvents or in PBS. It should be noted that the ${ }^{31} \mathrm{P}-\mathrm{NMR}$ signal linewidths of the silver complexes, are larger than those of the corresponding gold complexes, this being an indication for the rapid equilibria that silver compounds undergo in solution and for a greater lability of the bonds when gold is replaced with silver. In addition, no evidence of ${ }^{31} \mathrm{P}-107 / 109 \mathrm{Ag}$ coupling was found in our experimental conditions (i.e. at room temperature), being this a further confirmation of the above intepretation. ${ }^{19}$ Interestingly, when incubation is made in the Mueller-Hinton broth (i.e. the medium used for MIC determination) ${ }^{31} \mathrm{P}-\mathrm{NMR}$ peaks of silver complexes converge toward the same chemical species characterised by a ${ }^{31} \mathrm{P}$ chemical shift at $37.20 \mathrm{ppm}$. This observation supports the view that silver compounds, in the presence of the high concentration of peptides and amino acids of the broth, rapidly react leading to the same species likely originating from the coordination of aminoacidic residues to the silver center (see the supporting information for NMR spectra). No evidence for precipitation was found in the experimental conditions used. 
Table 3. MIC $(\mu \mathrm{g} / \mathrm{mL}$ and $\mu \mathrm{M})$ values obtained for silver compounds in Gram-positive strains and Candida albicans (strain 14). Strains features and notes are as in table 1.

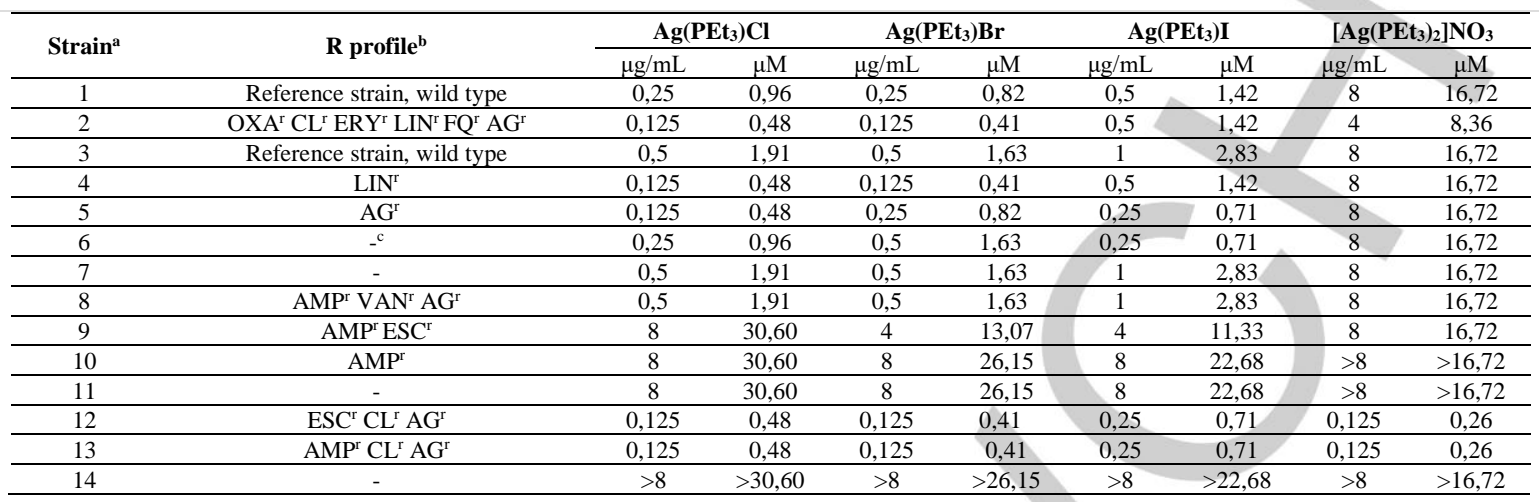

From comparative analysis of the obtained results it is evident that silver compounds are less effective than gold compounds; this means that replacement of gold $(\mathrm{I})$ with silver $(\mathrm{I})$ results in a general decrease of the antibacterial potency. This finding may sound rather surprising in light of the well-known antimicrobial properties of silver compounds. However, the lower stability of the silver complexes in the biological medium highlighted by the NMR experiments, may account for this net decrease in the pharmacological effects. Also, it can be observed that MIC values are similar for the $\mathrm{Ag}\left(\mathrm{PEt}_{3}\right) \mathrm{X}$ series except the case of the cationic complex $\left[\mathrm{Ag}\left(\mathrm{PEt}_{3}\right)_{2}\right] \mathrm{NO}_{3}$ for which the values are significantly larger. This result can be explained considering the nature of the ligands and the relative stability in the biological medium. Indeed, through comparative evaluation of the ${ }^{31} \mathrm{P}$ NMR spectra, it appears that after $72 \mathrm{~h}$ of incubation, complexes of the type $\mathrm{Ag}\left(\mathrm{PEt}_{3}\right) \mathrm{X}$ undergo a quantitative conversion leading to the appearance of the same multiplet signal at $37.2 \mathrm{ppm}$ (being this the predominant or the only signal, see the supporting information), assignable to a species where the halide ligands (or phosphine, to a minor extent), are replaced by sulphur or other coordinative atoms belonging to protein/peptides chains according to literature. ${ }^{19}$

On the contrary, for $\left[\mathrm{Ag}\left(\mathrm{PEt}_{3}\right)_{2}\right] \mathrm{NO}_{3}$, after $72 \mathrm{~h}$ of incubation, the peak assignable to the original species at $9.93 \mathrm{ppm}$ is still clearly detected alongside the signal at $37.20 \mathrm{ppm}$. Also, a less intense peak appears at $61 \mathrm{ppm}$, assignable to phosphine oxide (see the supporting information for NMR spectra). Thus, even for the silver cationic complex, we assist to a ligand displacement process, producing the same species as in the case of $\mathrm{Ag}\left(\mathrm{PEt}_{3}\right) \mathrm{X}$ compounds, with concomitant release of one triethyl phosphine ligand that is oxidized to the corresponding oxide. However, in this latter case the process is far slower.

Afterwards, the effects of silver compounds on the Gram-negative strains were studied. Results are reported in table 4.

Table 4. MIC ( $\mu \mathrm{g} / \mathrm{mL}$ and $\mu \mathrm{M})$ values obtained for silver compounds in Gram-negative strains in absence or in presence of polymyxin B nonapeptide (PMBN) as permeabilizing agent. Strains features and notes are as in table 2.

\begin{tabular}{|c|c|c|c|c|c|c|c|c|c|c|c|c|c|c|c|c|c|}
\hline \multirow{2}{*}{ Strain } & \multirow[t]{2}{*}{$\mathbf{R}$ profile } & \multicolumn{2}{|c|}{$\operatorname{Ag}\left(\mathbf{P E t}_{3}\right) \mathbf{C l}$} & \multicolumn{2}{|c|}{$\begin{array}{c}\mathrm{Ag}\left(\mathrm{PEt}_{3}\right) \mathrm{Cl} \\
\text { PMBN } \\
\end{array}$} & \multicolumn{2}{|c|}{$\operatorname{Ag}\left(\mathrm{PEt}_{3}\right) \mathbf{B r}$} & \multicolumn{2}{|c|}{$\begin{array}{c}\mathbf{A g}\left(\mathbf{P E t}_{3}\right) \mathbf{B r} \\
\text { PMBN } \\
\end{array}$} & \multicolumn{2}{|c|}{$\operatorname{Ag}\left(\mathbf{P E t}_{3}\right) \mathbf{I}$} & \multicolumn{2}{|c|}{$\begin{array}{l}\mathbf{A g}\left(\mathbf{P E t}_{3}\right) \mathbf{I} \\
\text { PMBN }\end{array}$} & \multicolumn{2}{|c|}{$\left[\mathrm{Ag}\left(\mathrm{PEt}_{3}\right)_{2}\right] \mathrm{NO}_{3}$} & \multicolumn{2}{|c|}{$\begin{array}{c}{\left[\mathrm{Ag}\left(\mathrm{PEt}_{3}\right)_{2}\right] \mathrm{NO}_{3}} \\
\text { PMBN } \\
\end{array}$} \\
\hline & & $\mu \mathrm{g} / \mathrm{mL}$ & $\mu \mathrm{M}$ & $\mu \mathrm{g} / \mathrm{mL}$ & $\mu \mathrm{M}$ & $\mu \mathrm{g} / \mathrm{mL}$ & $\mu \mathrm{M}$ & $\mu \mathrm{g} / \mathrm{mL}$ & $\mu \mathrm{M}$ & $\mu \mathrm{g} / \mathrm{mL}$ & $\mu \mathrm{M}$ & $\mu \mathrm{g} / \mathrm{mL}$ & $\mu \mathrm{M}$ & $\mu \mathrm{g} / \mathrm{mL}$ & $\mu \mathrm{M}$ & $\mu \mathrm{g} / \mathrm{mL}$ & $\mu \mathrm{M}$ \\
\hline 15 & $\mathrm{ESC}^{\mathrm{r}} \mathrm{NEM}^{\mathrm{r}} \mathrm{FQ}^{\mathrm{r}} \mathrm{AG}^{\mathrm{r}}$ & 2 & 7,56 & 1 & 3,82 & 2 & 6,54 & 1 & 3,27 & 4 & 11,33 & 2 & 5,67 & 8 & 19,70 & 8 & 19,70 \\
\hline 16 & $\begin{array}{c}\mathrm{ESC}^{\mathrm{r}} \mathrm{NEM}^{\mathrm{r}} \mathrm{FQ}^{\mathrm{r}} \mathrm{AG}^{\mathrm{r}} \\
\mathrm{COL}^{\mathrm{r}}\end{array}$ & 2 & 7,56 & 2 & 7,56 & 2 & 6,54 & 2 & 6,54 & 4 & 11,33 & 4 & 11,33 & 8 & 19,70 & 8 & 19,70 \\
\hline 17 & $\mathrm{ESC}^{\mathrm{r}} \mathrm{NEM}^{\mathrm{r}} \mathrm{FQ}^{\mathrm{r}} \mathrm{AG}^{\mathrm{r}}$ & 1 & 3,82 & 0,5 & 1,91 & 1 & 3,27 & 0,5 & 1,63 & 2 & 5,67 & 0,5 & 1,42 & 8 & 19,70 & 1 & 2,46 \\
\hline 18 & $\mathrm{NEM}^{\mathrm{r}} \mathrm{FQ}^{\mathrm{r}} \mathrm{AG}^{\mathrm{r}}$ & 0,5 & 1,91 & 0,5 & 1,91 & 0,5 & 1,63 & 0,5 & 1,63 & 2 & 5,67 & 1 & 2,83 & 2 & 4,92 & 2 & 4,92 \\
\hline 19 & - & 0,5 & 1,91 & 0,25 & 0,96 & 0,5 & 1,63 & 0,25 & 0,82 & 1 & 2,83 & 0,5 & 1,42 & 1 & 2,46 & 1 & 2,46 \\
\hline
\end{tabular}


The MIC values determined in Gram-negative strains, in line with the considerations on the stability, reveal that all silver compounds exhibit very similar antibacterial effects. Even in this case the lowest activity is seen for the cationic complex. Interestingly, in contrast with the results reported in table 2 for gold compounds, for which a strong enhancement of the antibacterial effects was evident, for silver compounds the activity in Gram-negative bacteria is poorly affected by pre-treatment with the permeabilising agent. Again, this finding may reflect the transformations occurring in the biological medium for the silver complexes.

\section{Conclusions}

In this work we have analyzed the stability profiles in different conditions (organic solvent, PBS, biological media) and the antimicrobial properties on clinical isolates of a small group of neutral gold(I) or silver(I) complexes of the type $\mathrm{M}\left(\mathrm{PEt}_{3}\right) \mathrm{X}$ $(\mathrm{M}=$ metal), as well as of selected complexes bearing a positive or negative charge i.e. $\left[\mathrm{Au}\left(\mathrm{PEt}_{3}\right)_{2}\right] \mathrm{Cl}, \mathrm{K}\left[\mathrm{Au}(\mathrm{CN})_{2}\right]$ and $\left[\mathrm{Ag}\left(\mathrm{PEt}_{3}\right)_{2}\right] \mathrm{NO}_{3}$ Comparative analysis of the results allows us to define some structure activity relationships as detailed below:

1. Stability experiments point out that in the applied experimental conditions, gold compounds are stable even for long incubation times, preserving their original structure; conversely, silver compounds, though stable in DMSO and PBS, do undergo ligand exchange reactions in $\mathrm{MH}$ broth eventually leading to formation of the same silver species.

2. The thiosugar ligand is not essential for the antimicrobial activity of AF and apparently does not favor an increased gold uptake.

3. The nature of the $X$ group in the $\mathrm{Au}\left(\mathrm{PEt}_{3}\right) \mathrm{X}$ series is not relevant for the activity; similar antimicrobial profiles were seen indeed for the three homologous complexes.

4. The gold-diphosphine cationic complex is as active as the $\mathrm{Au}\left(\mathrm{PEt}_{3}\right) \mathrm{X}$ derivatives implying that the positive charge and the presence of two phosphine ligands are not functionally relevant features.

5. Altogether, the above results point to the $\left[\mathrm{Au}\left(\mathrm{PEt}_{3}\right)\right]^{+}$moiety as the "true pharmacophore" in this series of metal complexes; their antimicrobial activity probably arises from gold coordination to appropriate targets after ligand exchange.

6. The anionic $\left[\mathrm{Au}(\mathrm{CN})_{2}\right]^{-}$complex shows a strongly reduced activity: this might be the consequence of the greater stability of the cyanide-gold bond.

7. Replacement of gold(I) with silver(I) causes a net reduction in the measured antimicrobial activity. This may be the consequence of the rather large instability of these complexes clelarly detected in the $\mathrm{MH}$ broth. Alternatively, the observed reduction in antimicrobial effects might be due to a reduced ability of silver (I) to inhibit bacterial targets.
8. Susceptibility of Gram-negative strains to gold compounds is increased in the presence of a permeabilizing agent (i.e. PMBN), indicating that one of the mechanisms of resistance to these compounds in such pathogens is their reduced uptake.

9. Among the various possible protein targets, in analogy with the case of auranofin, thioredoxin reductase might represent a likely target even for its gold and silver analogues. ${ }^{21}$

Thus, we have shown here that the comparative analysis of the respective antimicrobial profiles is a valid tool to select the "best performers" to be further evaluated as innovative and more efficient antimicrobial metal-based drugs. Hints are obtained to decipher the mechanism of action and to design better metal based antimicrobial agents and better drug combinations.

\section{Experimental Section}

\section{Chemicals and reagents}

Chemicals and reagents were purchased and used without further purification. Auranofin was obtained from Vinci Biochem ${ }^{\circledR}$. Commercially available $\mathrm{Au}\left(\mathrm{PEt}_{3}\right) \mathrm{Cl}$ was purchased by sigmaaldrich $^{\circledR}$.

\section{NMR Analysis}

NMR experiments were performed on Bruker Ultrashield 400 spectrometer. Calibration has been made on the residual peak of solvent. Raw data were elaborated through Topspin ${ }^{\circledR}$ software.

\section{UV-Vis analysis}

Spectrophotometric analysis of $\mathrm{K}\left[\mathrm{Au}(\mathrm{CN})_{2}\right]$ reported in supporting material was performed with a Varian Cary 50 Bio UV-Vis spectrophotometer.

\section{MIC values determination}

MICs were determined using a standard broth microdilution assay on 96-well plates, as recommended by the Clinical and Laboratory Standards Institute; ${ }^{22}$ assays were performed in triplicate using cation-supplemented Mueller-Hinton (MH) broth (Becton Dickinson, Franklin Lakes, NJ, USA) and a bacterial inoculum of $5 \times 10^{4} \mathrm{CFU} /$ well, in a final volume of $100 \mu \mathrm{l}$. AF, $\mathrm{Au}\left(\mathrm{PEt}_{3}\right) \mathrm{X}$ and $\mathrm{Ag}\left(\mathrm{PEt}_{3}\right) \mathrm{X}$ compounds were initially dissolved in DMSO and then diluted to the tested concentrations in $\mathrm{MH}$ broth; cationic diphosphine and anionic dicyano compounds were initially dissolved in sterile bidistilled water and then diluted as previously mentioned. Results were recorded after $18-20 \mathrm{~h}$ of incubation at $37^{\circ} \mathrm{C}$. For Gram-positive strains, the tested concentrations ranged from $0.062 \mu \mathrm{g} / \mathrm{mL}$ to $8 \mu \mathrm{g} / \mathrm{mL}$ for all the substances. MICs for Gram-negatives for the tested compounds, alone or in the presence of the permeabilizing agent polymyxin $B$ nonapeptide (PMBN), were determined as previously described for Grampositive strains. PMBN was used at a final concentration of 25 $\mu \mathrm{g} / \mathrm{mL} .{ }^{23}$ For these strains, $\mathrm{AF},\left[\mathrm{Au}\left(\mathrm{PEt}_{3}\right)_{2}\right] \mathrm{Cl}$ and $\mathrm{K}\left[\mathrm{Au}(\mathrm{CN})_{2}\right]$ were tested at concentrations from $0,25 \mu \mathrm{g} / \mathrm{mL}$ to $32 \mu \mathrm{g} / \mathrm{mL}$ while the remaining substances were tested at concentrations from 0,062 $\mu \mathrm{g} / \mathrm{mL}$ to $8 \mu \mathrm{g} / \mathrm{mL}$. MIC testing was carried out for all strains and compounds in at least three separate experiments. Major resistance features of the tested strains are shown in table 1 to 4 . 
Synthesis and characterisation of $\mathrm{Au}\left(\mathrm{PEt}_{3}\right) \mathrm{Br}$. $\mathrm{Au}\left(\mathrm{PEt}_{3}\right) \mathrm{Br}$ was prepared by modification of the reported method. ${ }^{24} 48.6 \mathrm{mg}$ of $\mathrm{Au}\left(\mathrm{PEt}_{3}\right) \mathrm{Cl}$ were stirred in $3 \mathrm{~mL}$ of dimethylformamide with five equivalents of $\mathrm{KBr}$ at $\mathrm{RT}$. After $18 \mathrm{~h}$ the mixture was dried under vacuum and the resulting solid was redissolved in a mixture of 10 $\mathrm{mL}$ of dichloromethane and $10 \mathrm{~mL}$ of demineralized $\mathrm{H}_{2} \mathrm{O}$. The mixture was moved in a separation funnel and further $10 \mathrm{~mL}$ of demineralized $\mathrm{H}_{2} \mathrm{O}$ were added. After separation, the aqueous phase was extracted another time with $10 \mathrm{~mL}$ of dichloromethane. The recombined organic phase was then washed with $20 \mathrm{~mL}$ of satured $\mathrm{NaCl}$ solution, dried with $\mathrm{Na}_{2} \mathrm{SO}_{4}$, filtered and evaporated under reduced pressure. The crude product was redissolved in 3 $\mathrm{mL}$ of $\mathrm{CHCl}_{3}$, then $7 \mathrm{~mL}$ of diethyl ether and $20 \mathrm{~mL}$ of hexane were added. The flask was kept at $-20^{\circ} \mathrm{C}$ for $96 \mathrm{~h}$ for allowing crystals to grow. Yield $73.6 \%(40.1 \mathrm{mg})$. Product was characterised through NMR, while purity was assessed through elemental analysis of $\mathrm{C}, \mathrm{N}$ and $\mathrm{H}$ [calculated $\mathrm{C}: 18.24 \%, \mathrm{H}: 3.83 \%, \mathrm{~N}: 0 \%$, experimental: C: $18.36 \%, \mathrm{H}: 3.55 \%, \mathrm{~N}: 0 \%] .{ }^{1} \mathrm{H}$ NMR $\left(\mathrm{CD}_{3} \mathrm{OD}\right.$, $400.13 \mathrm{MHz}, 298 \mathrm{~K}): 1.943\left(\mathrm{dq}, J_{\mathrm{HH}}=7.64 \mathrm{~Hz}, J_{\mathrm{HP}}=10.48 \mathrm{~Hz}\right.$, $6 \mathrm{H}) ; 1.215\left(\mathrm{dt}, J_{\mathrm{HH}}=7.60 \mathrm{~Hz}, J_{\mathrm{HP}}=19.12 \mathrm{~Hz}, 9 \mathrm{H}\right) .{ }^{13} \mathrm{C} \mathrm{NMR}$ $\left(\mathrm{CD}_{3} \mathrm{OD}, 100.61 \mathrm{MHz}, 298 \mathrm{~K}\right): 19.04\left(\mathrm{~d}, \mathrm{~J}_{\mathrm{CP}}=36.45 \mathrm{~Hz}\right) ; 9.44 .{ }^{31} \mathrm{P}$ NMR $\left(\mathrm{CD}_{3} \mathrm{OD}, 161.97 \mathrm{MHz}, 298 \mathrm{~K}\right): 36.38$ (supporting material for spectra).

Synthesis and characterisation of $\mathrm{Au}\left(\mathrm{PEt}_{3}\right) \mathrm{l} .40 \mathrm{mg}$ of commercially available $\mathrm{Au}\left(\mathrm{PEt}_{3}\right) \mathrm{Cl}$ were stirred in ethanol with five equivalents of $\mathrm{KI}$ at r.t. After $3 \mathrm{~h}$ the mixture was dried under vacuum and the resulting white solid kept at $-20^{\circ} \mathrm{C}$ over night. The product was then extracted five times with $3 \mathrm{~mL}$ of dichloromethane. The recombined organic phase was washed three times with $3 \mathrm{~mL}$ of water and dried with $\mathrm{MgSO}_{4}$. Solvent was evaporated in vacuum to a final volume of $3 \mathrm{~mL}$ and the product precipitated by addition of $50 \mathrm{~mL}$ of pentane. After filtration, the white product was dried in vacuum overnight. Yield $70 \%$. The product was characterized through NMR analysis. Purity of the product was assessed through elemental analysis of $\mathrm{C}, \mathrm{N}$ and $\mathrm{H}$ [calculated C: $16.30 \%, \mathrm{H}: 3.21 \%, \mathrm{~N}: 0 \%$, experimental: C: $16.01 \%$, $\mathrm{H}: 3.21 \%, \mathrm{~N}: 0 \%$ ]. ${ }^{1} \mathrm{H}$ NMR $\left(\mathrm{CD}_{3} \mathrm{OD}, 400.13 \mathrm{MHz}, 298 \mathrm{~K}\right) \delta: 1.955$ $\left(\mathrm{dq}, J_{\mathrm{HH}}=7.68 \mathrm{~Hz}, J_{\mathrm{HP}}=10.44 \mathrm{~Hz}, 6 \mathrm{H}\right) ; 1.235\left(\mathrm{dt}, J_{\mathrm{HH}}=7.60 \mathrm{~Hz}\right.$, $\left.J_{\mathrm{HP}}=19.12 \mathrm{~Hz}, 9 \mathrm{H}\right) .{ }^{13} \mathrm{C}$ NMR $\left(\mathrm{CD}_{3} \mathrm{OD}, 100.61 \mathrm{MHz}, 298 \mathrm{~K}\right) \delta$ : $19.20\left(\mathrm{~d}, J_{\mathrm{CP}}=34.55 \mathrm{~Hz}\right)$; 9.27. ${ }^{31} \mathrm{P} \mathrm{NMR}\left(\mathrm{CD}_{3} \mathrm{OD}, 161.97 \mathrm{MHz}\right.$, 298 K) $\delta: 41.17$ (supporting material for spectra).

Synthesis and characterization of $\left[\mathrm{Au}\left(\mathrm{PEt}_{3}\right)_{2}\right] \mathrm{Cl} .40 \mathrm{mg}$ of $\mathrm{Au}\left(\mathrm{PEt}_{3}\right) \mathrm{Cl}$ were stirred at r.t. and under inert conditions (Schlenk technique) with $1 \mathrm{~mL}$ of triethylphosphine solution $1 \mathrm{M}$ (10 eq) in tetrahydrofuran. After 3 hours stirring was stopped and the reaction mixture was kept under flowing nitrogen overnight for evaporating both tetrahydrofuran and unreacted triethylphosphine. After evaporation, the product was recovered in the form of big and colorless crystals. The crude product was dried under reduced pressure for removing all traces of unreacted materials. Yield $77 \%$. The product was characterized through NMR analysis. Purity of the product was assessed through elemental analysis of $\mathrm{C}, \mathrm{N}$ and $\mathrm{H}$ [calculated $\mathrm{C}: 30.75 \%, \mathrm{H}: 6.45 \%, \mathrm{~N}: 0 \%$, experimental: C: $31.28 \%, \mathrm{H}: 6.25 \%, \mathrm{~N}: 0 \%] .{ }^{1} \mathrm{H}$ NMR $\left(\mathrm{CD}_{3} \mathrm{OD}\right.$, $400.13 \mathrm{MHz}, 298 \mathrm{~K}) \delta: 2.055$ (q, JHH $=7.64 \mathrm{~Hz}, 12 \mathrm{H}) ; 1.264$ (broad $18 \mathrm{H}) .{ }^{13} \mathrm{C}$ NMR $\left(\mathrm{CD}_{3} \mathrm{OD}, 100.61 \mathrm{MHz}, 298 \mathrm{~K}\right) \delta: 19.20$ (broad); 9.43. ${ }^{31} \mathrm{P}$ NMR $\left(\mathrm{CD}_{3} \mathrm{OD}, 161.97 \mathrm{MHz}, 298 \mathrm{~K}\right) \delta: 47.83$ (supporting material for spectra).
Synthesis and characterization of $\mathrm{K}\left[\mathrm{Au}(\mathrm{CN})_{2}\right]$. BE CAREFUL. SOME STEP OF THIS REACTION IMPLIES THE USE OF FULMINATING GOLD (EXPLOSIVE COMPOUND) AND KCN (HIGHLY TOXIC). K[Au(CN $\left.)_{2}\right]$ was synthesized modifying a reported method. ${ }^{25} 2.5 \mathrm{~mL}$ of a $1 \mathrm{M}$ solution of $\mathrm{HAuCl}_{4}$ were stirred in a beaker with $10 \mathrm{~mL}$ of $\mathrm{NH}_{3} 3 \mathrm{M}$. The formed suspension was gently warmed (about $60{ }^{\circ} \mathrm{C}$ ) for 3 hours. Subsequently the formed fulminating gold was careflully filtered on a buchner and well washed with distilled water. For avoiding explosions, in this step fulminating gold was kept wet. The moist product was entirely moved in a beaker with the filter and $20 \mathrm{~mL}$ of distilled water were added. The suspension was stirred at r.t. and $350 \mathrm{mg}(2.15 \mathrm{eq})$ of $\mathrm{KCN}$ were added and the mixture turned quickly to a pale red limpid solution. The white crystalline product was precipitated by evaporation, gently heating the solution under stirring. The crude product was then washed on buchner with $2 \mathrm{~mL}$ of ethanol and dried under reduced pressure. The pure product (252.6 mg; yield $35.1 \%$ ) was characterised by UV-vis spectroscopy and ${ }^{13} \mathrm{CNMR}$. Purity of the product was assessed through elemental analysis of $\mathrm{C}, \mathrm{N}$ and $\mathrm{H}$ [calculated $\mathrm{C}: 8.34 \%, \mathrm{H}: 0.00 \%, \mathrm{~N}: 9.72 \%$, experimental: C: $8.46 \%, \mathrm{H}: 0.00 \%, \mathrm{~N}: 9.88 \%]$. UV-vis $\left(\mathrm{KAu}(\mathrm{CN})_{2}\right.$ $10^{-4} \mathrm{M}$, Buffer Phosphate pH 7.4): $205 \mathrm{~nm} ; 212 \mathrm{~nm} ; 230 \mathrm{~nm} ; 240$ nm. ${ }^{13} \mathrm{C}$ NMR $\left(\mathrm{D}_{2} \mathrm{O}, 100.61 \mathrm{MHz}, 298 \mathrm{~K}, 72 \mathrm{~h}\right) \delta: 154.97$ (supporting material for spectra).

Synthesis and characterisation of $\mathbf{A g}\left(\mathrm{PEt}_{3}\right) \mathrm{Cl} . \mathrm{Ag}\left(\mathrm{PEt}_{3}\right) \mathrm{Cl}$ was synthesized by addition, under inert conditions, of $200 \mathrm{mg}$ of $\mathrm{AgCl}$ to $1.1 \mathrm{~mL}$ of $\mathrm{PEt}_{3} 1 \mathrm{M}$ (0.8 equivalents) in tetrahydrofuran. The heterogeneous mixture was stirred at r.t. for 4 hours, then the liquid phase was evaporated under reduced pressure. The crude product was suspended in $5 \mathrm{~mL}$ of dichloromethane and the solid was filtered off. The liquid phase was evaporated and $260 \mathrm{mg}$ of pure product were obtained (yield 71.6\%). Elemental analysis: calculated C: $27.56 \%, \mathrm{H}: 5.78 \%$; experimental C: $27.93 \%, \mathrm{H}$ : 5.82\%. ${ }^{1} \mathrm{H}$ NMR $\left(\mathrm{CD}_{3} \mathrm{OD}, 400.13 \mathrm{MHz}, 298 \mathrm{~K}\right) \delta: 1.764(\mathrm{~m}, 6 \mathrm{H})$; $1.193\left(\mathrm{dt}, J_{\mathrm{HH}}=7.66 \mathrm{~Hz}, J_{\mathrm{HP}}=17.96 \mathrm{~Hz}, 9 \mathrm{H}\right) .{ }^{13} \mathrm{C} \mathrm{NMR}\left(\mathrm{CD}_{3} \mathrm{OD}\right.$, 100.61 MHz, $298 \mathrm{~K}) \delta: 18.07\left(\mathrm{~d}, J_{\mathrm{CP}}=18.70 \mathrm{~Hz}\right)$; 9.76. ${ }^{31} \mathrm{P}$ NMR $\left(\mathrm{CD}_{3} \mathrm{OD} ; 161.97 \mathrm{MHz}, 298 \mathrm{~K}\right)$ : 8.83 (supporting material for spectra).

Synthesis and characterisation of $\mathbf{A g}\left(\mathrm{PEt}_{3}\right) \mathrm{Br}$. $\mathrm{Ag}\left(\mathrm{PEt}_{3}\right) \mathrm{Br}$ was synthesized by addition, under inert conditions, of $300 \mathrm{mg}$ of $\mathrm{AgBr}$ to $1.2 \mathrm{~mL}$ of $\mathrm{PEt}_{3} 1 \mathrm{M}$ (0.8 equivalents) in tetrahydrofuran. The heterogeneous mixture was stirred at r.t. for 3 hours, then the liquid phase was evaporated under reduced pressure. The crude product was suspended in $5 \mathrm{~mL}$ of dichloromethane and the solid was filtered off. The liquid phase was evaporated and $380 \mathrm{mg}$ of pure product were obtained (yield $77.8 \%$ ). Elemental analysis: calculated C: $23.56 \%, \mathrm{H}: 4.94 \%$; experimental C: $23.73 \%, \mathrm{H}$ : 5.33\%. ${ }^{1} \mathrm{H}$ NMR $\left(\mathrm{CD}_{3} \mathrm{OD}, 400.13 \mathrm{MHz}, 298 \mathrm{~K}\right) \delta: 1.747(\mathrm{~m}, 6 \mathrm{H})$; $1.193\left(\mathrm{dt}, J_{\mathrm{HH}}=7.65 \mathrm{~Hz}, J_{\mathrm{HP}}=17.73 \mathrm{~Hz}, 9 \mathrm{H}\right) .{ }^{13} \mathrm{C} \mathrm{NMR}\left(\mathrm{CD}_{3} \mathrm{OD}\right.$, 100.61 MHz, $298 \mathrm{~K}) \delta: 18.19$ (b); 9.71. ${ }^{31} \mathrm{P}$ NMR ( $\mathrm{CD}_{3} \mathrm{OD} ; 161.97$ $\mathrm{MHz}, 298 \mathrm{~K}) \delta: 6.68$ (supporting material for spectra).

Synthesis and characterisation of $\mathbf{A g}\left(\mathrm{PEt}_{3}\right) \mathbf{l}$. $\mathrm{Ag}\left(\mathrm{PEt}_{3}\right) \mathbf{l}$ was synthesized by addition, under inert conditions, of $260 \mathrm{mg}$ of $\mathrm{Agl}$ to $0.9 \mathrm{~mL}$ of $\mathrm{PEt}_{3} 1 \mathrm{M}$ (0.8 equivalents) in tetrahydrofuran. The heterogeneous mixture was stirred at r.t. for 1.5 hours, then the liquid phase was evaporated under reduced pressure. The crude product was suspended in $5 \mathrm{~mL}$ of dichloromethane and the solid was filtered off. The liquid phase was evaporated and $270 \mathrm{mg}$ of 
pure product were obtained (yield 79.7\%). Elemental analysis: calculated C: $20.42 \%, \mathrm{H}: 4.28 \%$; experimental C: $20.51 \%, \mathrm{H}$ : 4.36\%. ${ }^{1} \mathrm{H}$ NMR $\left(\mathrm{CDCl}_{3}, 400.13 \mathrm{MHz}, 298 \mathrm{~K}\right) \delta: 1.664$ (m, 6H); $1.169\left(\mathrm{dt}, J_{\mathrm{HH}}=7.99 \mathrm{~Hz}, J_{\mathrm{HP}}=15.98 \mathrm{~Hz}, 9 \mathrm{H}\right) .{ }^{13} \mathrm{C} \mathrm{NMR}\left(\mathrm{CDCl}_{3}\right.$, $100.61 \mathrm{MHz}, 298 \mathrm{~K}) \delta: 18.53\left(\mathrm{~d}, J_{\mathrm{CP}}=12.74 \mathrm{~Hz}\right) ; 10.39 .{ }^{31} \mathrm{P}$ NMR $\left(\mathrm{CDCl}_{3} ; 161.97 \mathrm{MHz}, 298 \mathrm{~K}\right) \delta$ : -8.39 (supporting material for spectra).

Synthesis and characterisation of $\left[\mathrm{Ag}\left(\mathrm{PEt}_{3}\right)_{2}\right] \mathrm{NO}_{3}$. $\left[\mathrm{Ag}\left(\mathrm{PEt}_{3}\right)_{2}\right] \mathrm{NO}_{3}$ was synthesized by addition, under inert conditions, of $162.1 \mathrm{mg}$ of $\mathrm{AgNO}_{3}$ to $1.9 \mathrm{~mL}$ of $\mathrm{PEt}_{3} 1 \mathrm{M}$ in tetrahydrofuran (2 equivalents). After a few seconds the solid was totally solubilized. The solution was stirred at r.t. for 2 hours, then the solvent and the unreacted phosphine were removed under reduced pressure. $335.2 \mathrm{mg}$ of viscous liquid were obtained (yield $86.5 \%$ ). The product was characterised through ${ }^{1} \mathrm{H},{ }^{31} \mathrm{P}$ and ${ }^{13} \mathrm{C}$ NMR. Purity of the product was assessed through elemental analysis of $\mathrm{C}, \mathrm{N}$ and $\mathrm{H}$ [calculated $\mathrm{C}: 35.48 \%, \mathrm{H}: 7.44 \%, \mathrm{~N}: 3.45 \%$, experimental: $\mathrm{C}: 35.79 \%, \mathrm{H}: 7.47 \%, \mathrm{~N}: 3.30 \%] .{ }^{1} \mathrm{H}$ NMR $\left(\mathrm{CD}_{3} \mathrm{OD}\right.$, $400.13 \mathrm{MHz}, 298 \mathrm{~K}) \delta: 1.787(\mathrm{~m}, 12 \mathrm{H}) ; 1.190(\mathrm{~b}, 18 \mathrm{H}) .{ }^{13} \mathrm{C}$ NMR $\left(\mathrm{CD}_{3} \mathrm{OD}, 100.61 \mathrm{MHz}, 298 \mathrm{~K}\right) \delta: 17.85\left(\mathrm{~d}, \mathrm{~J}_{\mathrm{CP}}=12.55 \mathrm{~Hz}\right) ; 9.72$. ${ }^{31} \mathrm{P}$ NMR $\left(\mathrm{CD}_{3} \mathrm{OD} ; 161.97 \mathrm{MHz}, 298 \mathrm{~K}\right)$ : 8.49 (supporting material for spectra).

\section{Acknowledgements}

We gratefully acknowledge Beneficentia Stiftung (Vaduz), ITT (Istituto Toscano Tumori), Fondazione Cassa Risparmio Firenze (CRF), AIRC (IG-16049) COST Action CM1105 for financial support. T.M. thanks AIRC-FIRC (Fondazione Italiana per la Ricerca sul Cancro, 3-years Fellowship for Italy. Project Code: 18044). CIRCMSB is also acknowledged.

Keywords: Auranofin - Antimicrobial drugs • Drug repositioning - Drug resistance $\cdot$ Gold compounds

\section{References:}

[1] T.G. Benedek, J. Hist. Med. Allied Sci. 2004, 59, 50-89.

[2] C.F. Shaw III, Chem. Rev. 1999, 99, 2589-2600.

[3] S. Singh, R. Sivakumar, J. Infect. Chemother. 2004, 10, 307-315

[4] J.A. Lemire, J.J Harrison, R.J Turner, Nat. Rev. Microbiol. 2013, 11, 371 384.

[5] N. Farrell, "Metal Complexes as Drugs and Chemotherapeutic Agents", from Comprehensive Coordination Chemistry II, Edited by J.A. McCleverty, T.J. Meyer, 2004, 9, 809.

[6] C.L. Ventola, P\&T, 2015, 40, 277-283

[7] a) M.I.Cassetta, T. Marzo, S. Fallani, A. Novelli, L. Messori, Biometals 2014, 27, 787; b) J.P. Owings, N.N. McNair, Y.F. Mui, T.N. Gustafsson, A. Holmgren, M. Contel, J.B. Goldberg, J.R. Mead, FEMS Microbiol. Lett. 2016, 363, 14: fnw148; c) Y. Hokai, B. Jurkowicz, J. Fernández-Gallardo, N. Zakirkhodjaev, M. Sanaú, T.R. Muth, M. Contel, J. Inorg. Biochem. 2014, 138, 81-88; d) N.S. Torres, J.J. Abercrombie, A. Srinivasan, J.L. Lopez-Ribot, A.K. Ramasubramanian, K.P. Leung, Antimicrob. Agents Ch. 2016, 60, 5663-5672; e) J.M. Madeira, D.L. Gibson, W.F. Kean, A Klegeris, Inflammopharmacology 2012, 20, 297-306; f) L. Aguinagalde, R. Díez-Martínez, J. Yuste, I. Royo, C. Gil, Í. Lasa, M. Martín-Fontecha N.I. Marín-Ramos, C. Ardanuy, J. Liñares, P. Garcí, E. Garcí, J.M Sánchez-Puelles, J. Antimicrob. Chemother. 2015, 70, 2608-2617; g) C. Roder, M.J. Thomson, Drugs in R. and D. 2015, 15, 13-20.

[8] a) P. Hikisz, Ł. Szczupak, A. Koceva-Chyła, A. Gu Spiel, L. Oehninger, I. Ott, B. Therrien, J. Solecka, K. Kowalski, Molecules. 2015, 20, 19699-
19718; b) B.-J.Chen, N.S. Jamaludin, C.-H. Khoo, T.-H. See, J.-H. Sim, Y.-K. Cheah, S.N.A Halim, H.-L Seng, E.R.T. Tiekink, J. Inorg. Biochem 2016, 163, 68-80; c) V. Andermark, K. Göke, M. Kokoschka, M.A. Abu E Maaty, C.T. Lum, T. Zou, R.W.-Y. Sun, E. Aguiló, L. Oehninger, L. Rodríguez, H. Bunjes, S. Wölfl, C.-M Che, I. Ott, J. Inorg. Biochem. 2016, 160, 140-148; d) L. Ortego, J. Gonzalo-Asensio, A. Laguna, M.D Villacampa, M.C. Gimeno, J. Inorg. Biochem. 2015, 146, 19-27; e) A. AbdelKhalek, N.S. Abutaleb, K.A. Elmagarmid, M.N. Seleem, Sci Rep. 2018, 8, 8353

[9] S. Jackson-Rosario, D. Cowart, A. Myers, R. Tarrien, R.L. Levine, R. Scott, W.T. Self, J. Biol. Inorg. Chem. 2009, 14, 507-519.

[10] T. Shankar, M. Haroon, A.F.N. Mostafa, T.J.P. Sobreira, V.E. Hedrick, L.N. Paul, M.N. Seleem, Sci. Rep. 2016, 6, 22571.

[11] S.E. Jackson-Rosario, W.T. Self, J. Bacteriol. 2009, 191, 4035-4040.

[12] S.E. Jackson-Rosario, W.T. Self, Metallomics 2010, 2, 112-116.

[13] a) B.M. Sutton, E. McGusty, D.T. Walz, M.J. DiMartino, J. Med Chem. 1972, 15, 1095-1098; b) M. El-Etri and W.M. Scovell, Inorg. Chem. 1990, 29, 480-484; c) T. Marzo, D. Cirri, C. Gabbiani, T. Gamberi, F. Magherini, A. Pratesi, A. Guerri, T. Biver, F. Binacchi, M. Stefanini, A. Arcangeli, L. Messori, ACS med. chem. Lett. 2017, 8, 997-1001.

[14] a) M.J. Mays and P.A. Vergnano, J. Chem. Soc., Dalton Trans., 1979, 0 , 1112-1115; b) G. Brauer Handbook of Preparative Inorganic Chemistry Academic Press, New York (1965) 1065-1066.

[15] L. Messori, L. Marchetti, L. Massai, F. Scaletti, A. Guerri, I. Landini, S. Nobili, G. Perrone, E. Mini, P. Leoni, M. Pasquali, C. Gabbiani, Inorg. Chem. 2014, 53, 2396-2403.

[16] M.C. Crudden, D.P Allen, Coordin. Chem. Rev. 2004, 248, 2247-2273.

[17] H. Tsubery, I. Ofek, S. Cohen, M. Fridkin, J. Med. Chem. 2000, 43, 3085 3092, and references therein.

[18] A. Cannatelli, M.M. D'Andrea, T. Giani, V. Di Pilato, F. Arena, S. Ambretti, P. Gaibani, G.M. Rossolini, Antimicrob Agents Chemother. 2013, 57, 5521-5526.

[19] S.J. Berners-Price, R.K. Johnson, Al J. Giovenella, L.F. Faucette, C.K Mirabelli, P.J. Sadler, J. Inorg. Biochem. 1988, 33, 285-95.

[20] a) M.R. Churchill and B. G. DeBoer, Inorganic Chemistry, 1975, 14, 2502-2507; b) M.R. Churchill, J. Donahue and FJ. Rotella, Inorg. Chem., 1976, 15, 2752-2758.

[21] M.B. Harbut, C. Vilchèze, X. Luo, M.E. Hensler, H. Guo, B. Yang, A.K. Chatterjee, V. Nizet, W.R. Jr. Jacobs, P.G. Schultz, F. Wang Proc. Natl. Acad. Sci. U S A 2015, 112, 4453-4458.

[22] Clinical and Laboratory Standards Institute. Methods for dilution antimicrobial susceptibility tests for bacteria that grow aerobically. 2015 Approved standard-Tenth Edition M07-A10. CLSI, Wayne, PA, USA.

[23] D. Schneider, A. Schier, H. Schmidbaua, Dalton Trans. 2004, 13, 19952005.

[24] P. Viljanen P, M. Vaara, Antimicrob. Agents Chemother. 1984, 25, 701 705.

[25] P.M. Yangyuoru, J.W. Webb, C.F. Shaw III, J. Inorg. Biochem. 2008, 102, 584-593. 


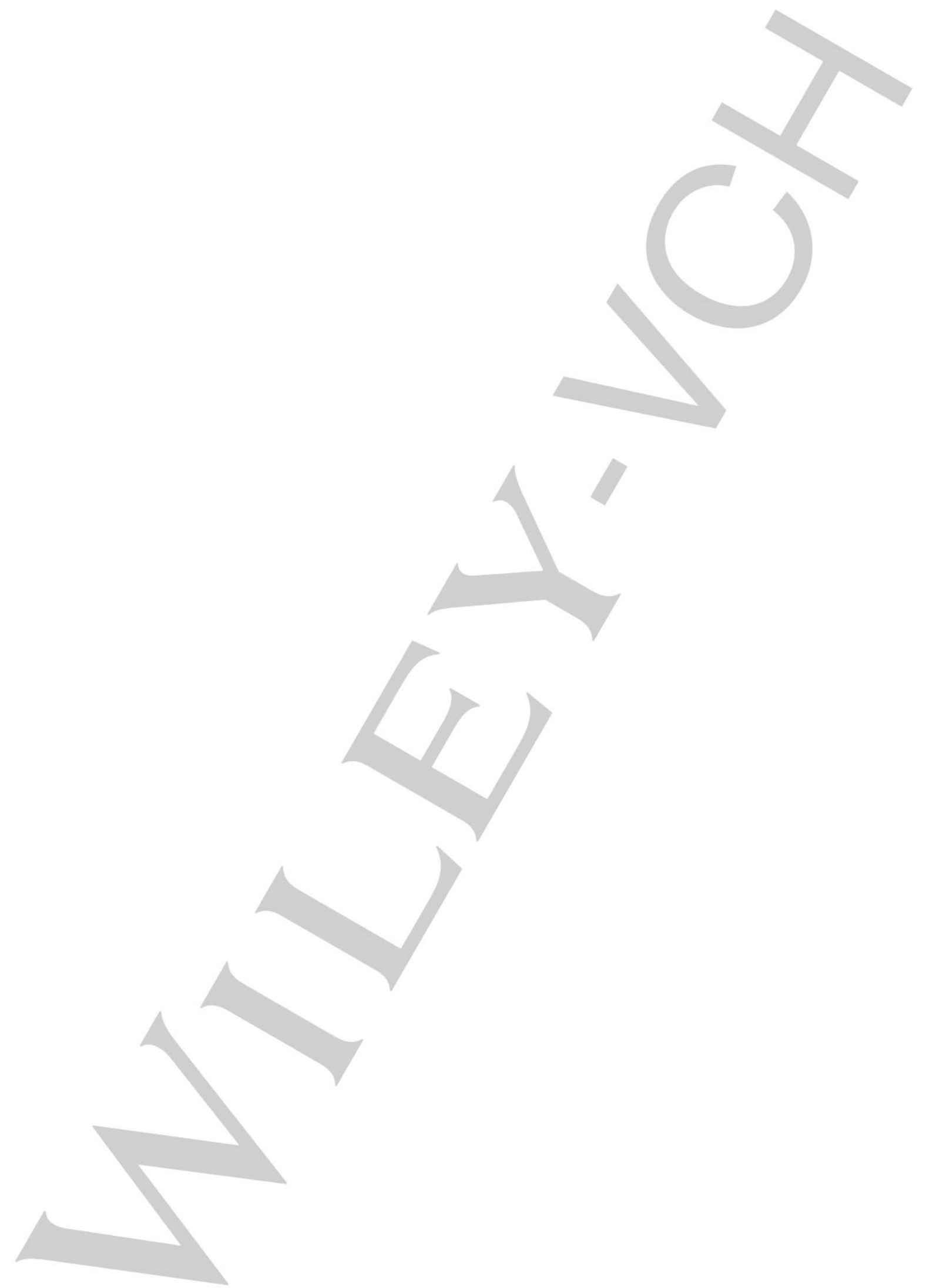




\section{Entry for the Table of Contents}

We have analyzed the antimicrobial properties of a small group of metal complexes with general formula $M\left(P E t_{3}\right) X($ with $M=A u$ or $A g$, and $\mathrm{X}=\mathrm{Cl}, \mathrm{Br}$ or I) alongside with three complexes bearing a positive or negative charge i.e. $\left.\left[\mathrm{Au}(\mathrm{PEt})_{3}\right)_{2}\right] \mathrm{Cl}, \mathrm{K}\left[\mathrm{Au}(\mathrm{CN})_{2}\right]$ and $\left[\mathrm{Ag}\left(\mathrm{PEt}_{3}\right)_{2}\right] \mathrm{NO}_{3}$. Stability of complexes in the experimental conditions is shown to be a key feature and the main mechanism for resistance in Gram-negative strains is a reduced uptake. Hints are obtained to design better metal based antimicrobial agents.

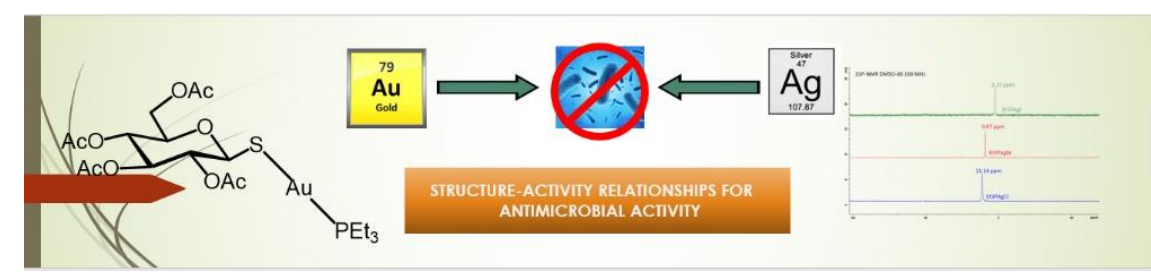

